\title{
Developmental and pathological lymphangiogenesis: from models to human disease
}

\author{
Hélène Maby-El Hajjami · Tatiana V. Petrova
}

Accepted: 2 October 2008 / Published online: 23 October 2008

(C) The Author(s) 2008. This article is published with open access at Springerlink.com

\begin{abstract}
The lymphatic vascular system, the body's second vascular system present in vertebrates, has emerged in recent years as a crucial player in normal and pathological processes. It participates in the maintenance of normal tissue fluid balance, the immune functions of cellular and antigen trafficking and absorption of fatty acids and lipidsoluble vitamins in the gut. Recent scientific discoveries have highlighted the role of lymphatic system in a number of pathologic conditions, including lymphedema, inflammatory diseases, and tumor metastasis. Development of genetically modified animal models, identification of lymphatic endothelial specific markers and regulators coupled with technological advances such as high-resolution imaging and genome-wide approaches have been instrumental in understanding the major steps controling growth and remodeling of lymphatic vessels. This review highlights the recent insights and developments in the field of lymphatic vascular biology.
\end{abstract}

Keywords Lymphangiogenesis - Lymphedema · Tumor metastasis $\cdot$ Inflammation

H. Maby-El Hajjami · T. V. Petrova ( $₫)$

Division of Experimental Oncology,

Centre Pluridisciplinaire d'Oncologie,

CHUV and University of Lausanne,

Ch. des Boveresses 155, 1066 Epalinges, Switzerland

e-mail: tatiana.petrova@unil.ch

T. V. Petrova

Molecular and Cancer Biology Research Program,

University of Helsinki, Haartmaninkatu 8,

P.O. Box 63, 00014 Helsinki, Finland

\section{Introduction}

The complexity of the circulatory networks of animals tends to increase as species increase in size. Apart from the cardiovascular system, vertebrates also possess a lymphatic system that consists of the lymphatic vessels and the lymphoid organs such as lymph nodes, mucosal-associated lymphoid tissue (MALT) (tonsils, Peyer's patches, and lymphoid tissues associated to the bronchial and nasal systems), spleen, and thymus. Blood and lymphatic vessels comprise two interdependent vascular networks in most tissues; however, their organization and function are distinct. The cardiovascular system forms a continuous loop around which the heart pumps blood, whereas the lymphatic system comprises a one-way, open-ended transit network without a central driving force. Blood vessels deliver blood cells, nutrients, hormones, and oxygen to tissues, whereas lymphatic vasculature removes macromolecules, microbes, and other substances from interstitial space.

The lymphatic system comprises a network of blindended lymphatic capillaries (also called initial lymphatic vessels) that collect the excess extravasated tissue fluid that has originated as capillary infiltration from the blood serum (Fig. 1). After being collected by the lymphatic capillaries, the lymph is transported through a system of lymphatic vessels of progressively larger size, to pre-collector lymphatic vessels (Sacchi et al. 1997) then larger collecting lymphatic vessels, which converge into lymphatic trunks, and the lymph is finally returned to the venous circulation via a connection with subclavian veins (Casley-Smith 1980; Moore 1985). Thus the main function of the lymphatic system is to maintain normal tissue fluid balance by restoring interstitial fluid to the cardiovascular system. In addition, in the digestive tract, lacteal lymphatic vessels inside the intestinal villi absorb and transport fat-soluble vitamins 


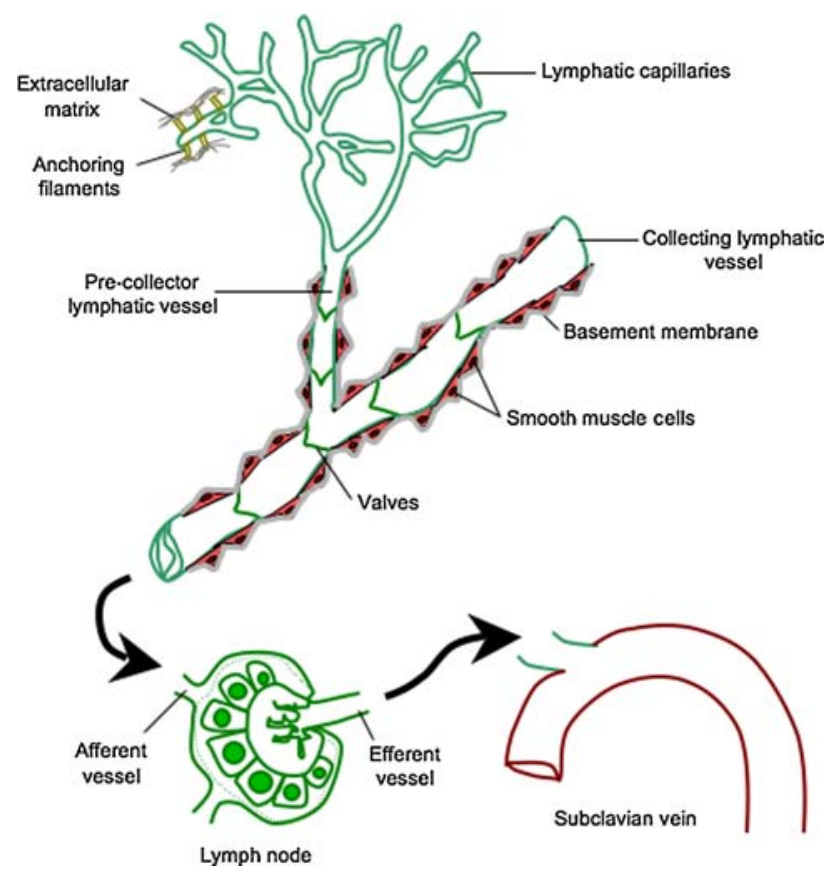

Fig. 1 Organization of lymphatic vascular system. The lymph is collected by a network of blind-ended lymphatic capillaries and is transported by pre-collector lymphatic vessels and collecting lymphatic vessels, which are emptied into veins in the jugular region. Lymphatic capillaries consist of thin-walled lymphatic endothelial cells with overlapping junctions which look like valves. Anchoring filaments, containing fibrillin, connect lymphatic capillaries to the extracellular matrix and prevent vessel collapse during increased interstitial pressure. The pre-collector and collecting lymphatic vessels have a basement membrane, are surrounded by smooth muscle cells (red) and contain intraluminal valves that prevent lymph blackflow

(A, D, E, and $\mathrm{K}$ ) and dietary fat, released by enterocytes in the form of lipid particles called chylomicrons. Furthermore, the lymphatic system is an important part of immune surveillance by carrying antigens and antigen presenting cells from the interstitium to be displayed for $\mathrm{B}$ and $\mathrm{T}$ cells in the lymph nodes. In addition to these physiological tasks the lymphatic system plays a major role in a number of pathologic conditions, including lymphedema, inflammatory diseases, and tumor metastasis.

Present in the skin and in most internal organs, with the exception of avascular structures such as epidermis, hair, nails, cartilage, and cornea, and some vascularised organs such as the brain, bone marrow, and retina, the lymphatic vasculature is composed of vessels with distinct morphological features (Fig. 1). Similar to blood capillaries, lymphatic capillaries consist of a single layer of thin-walled, non-fenestrated lymphatic endothelial cells (LECs), but they differ in that they are not ensheathed by pericytes or smooth muscle cells (SMCs), and have an absent or poorly developed basement membrane. In addition, they lack tight junctions and adherens junctions, which allow easy access for fluid, macromolecules, and cells into the vessel lumen
(Leak 1976). Endothelial cells of lymphatic capillaries are oak leaf shaped and are interconnected by specialized discontinuous button-like junctions, whereas collecting lymphatic vessels downstream have continuous zipper-like junctions found also in blood vessels (Baluk et al. 2007). Overlapping endothelial cell-cell contacts (also called primary valves) in initial lymphatic vessels prevent fluid escaping back into the interstitial space (Schmid-Schönbein 2003; Trzewik et al. 2001). Lymphatic capillary endothelial cells are closely linked to the surrounding extracellular matrix by elastic fibers known as anchoring filaments (Gerli et al. 1991; Leak and Burke 1968), which prevent vessel collapse in conditions of high interstitial pressure, indeed in this condition the junctions of the initial lymphatics open and the anchoring filaments stretch, allowing fluid to move into the vessel. Anchoring filaments are made of fibrillin (Gerli et al. 2000; Solito et al. 1997), a large glycoprotein that contains an Arg-Gly-Asp (RGD) motif capable of binding $\alpha \mathrm{v} \beta 3$ integrins, which are transmembrane glycoproteins that cluster at focal adhesion plaques. Pre-collector lymphatic vessels are characterized by the alternation of areas with the same structural simplicity as initial lymphatic capillaries and areas with a well-developed muscular coat, but the ultrastructural features of these different portions do not differ, and anchoring filaments are present in both (Scavelli et al. 2004). The pre-collecting lymphatic vessels merge into collecting lymphatic vessels, and the two types of vessels have a basement membrane, and are surrounded by SMCs with intrinsic contractile activity to promote lymph flow. The latter is also due to the contraction of surrounding skeletal muscles, as well as arterial pulsations. Like veins, the larger lymphatic vessels contain one-way intraluminal valves that aid in lymph propulsion by preventing backflow (Leak and Burke 1966; von der Weid and Zawieja 2004). Compared to blood vessels, the lymphatic vasculature is a low flow and low pressure system.

\section{Development of lymphatic vasculature}

Embryonic development concepts

The first description of the lymphatic system dates back to the seventeenth century, when Gasparo Aselli identified lymphatic vessels as "milky veins" in the mesentery of a "well-fed" dog (Asellius 1627). However, the embryonic origin of lymphatic vessels remained unclear for a long time until F. Sabin $(1902,1909)$ and F. Lewis $(1905)$ postulated, at the beginning of the twentieth century, that LECs are derived from the venous endothelium. This "centrifugal" theory proposes that endothelial cells bud off from the veins during early embryonic development and form primitive lymph sacs in the jugular region (reviewed by Oliver 
2004). From these sacs, budding endothelial cells centrifugally sprout towards the periphery, forming capillaries that surround tissues and organs. An alternative, "centripetal" theory, suggests that LECs are derived from mesenchymal progenitor cells, which, nowadays, are called lymphangioblasts (Huntington and Mc Clure 1910). Several recent studies in genetically engineered mouse models (Srinivasan et al. 2007; Wigle et al. 2002; Wigle and Oliver 1999) and in vivo imaging of developing lymphatic vasculature in zebrafish (Yaniv et al. 2006) provide strong support for the venous origin of lymphatic vessels. Lineage tracing experiments demonstrate that LECs originating in embryonic veins are the main source for the developing lymphatic vasculature; they have also identified some of the molecular determinants that control the step-wise process of lymphatic competence, commitment, differentiation and maturation (reviewed in Adams and Alitalo 2007; Karpanen and Alitalo 2008; Oliver 2004).

An intermediate position favouring a dual origin from embryonic veins and mesenchymal lymphangioblasts is also proposed. Grafting experiments in avian embryos suggest that while the deep parts of the lymph sacs are derived from adjacent veins, the superficial parts of the jugular lymph sacs and the dermal lymphatics arise from local lymphangioblasts (Wilting et al. 2006). In Xenopus tadpoles, PROX1positive mesodermal precursor cells, lymphangioblasts, which share a common origin with vascular progenitor cells, contribute to lymphatic vessel formation (Ny et al. 2005). In murine embryos, scattered mesenchymal cells, which coexpress leukocyte (CD45) and lymphatic endothelial markers (LYVE-1, PROX1), were detected in the regions of new lymphatic vessel growth; and it was suggested that the triple positive cells $\left(\mathrm{LYVE}-1^{+}, \mathrm{PROX} 1^{+}, \mathrm{F} 4 / 80^{+}\right.$) with characteristics of LECs and macrophages may integrate into lymphatic vessels (Buttler et al. 2006, 2008a). The functional role of such cells remains unclear, as formation of lymph sacs is not affected in Runx $1^{-1-}$ mice, which have defective hematopoiesis, and lineage tracing studies failed to demonstrate contribution of hematopoietic cells to lymphatic endothelium up to the embryonic day E16.5 (Buttler et al. 2008b; Srinivasan et al. 2007). A possibility remains that hematopoietic cells contribute to developmental lymphangiogenesis in a noncell autonomous manner, as described previously for angiogenesis (Takakura et al. 2000).

In adults, similar to blood vessels, the lymphatic vasculature remains in quiescent state with the exception of situations of tissue and organ regeneration, wound healing, tumor growth, and in inflammation. New lymphatic vessels primarily grow by sprouting from existing ones; in addition, the hematopoietic cell-derived circulating endothelial progenitors and transdifferentiating macrophages are putative sources of LECs during pathological lymphangiogenesis, such as during chronic renal transplant rejection or corneal lymphangiogenesis (Maruyama et al. 2005; Religa et al. 2005; Schledzewski et al. 2006). However, bone marrow-derived progenitor cells did not incorporate significantly into the endothelium of newly formed lymphatic vessels in mouse tumor xenografts (He et al. 2004), and more generally, a growing body of evidence suggest that circulating bone marrow-derived progenitor cells may promote growth of vessels mainly by acting as supporting cells (Grunewald et al. 2006; Purhonen et al. 2008).

Mechanisms of lymphatic vascular development

\section{Lymphatic endothelial cell fate commitment}

During embryogenesis, the development of lymphatic vessels starts after the establishment of a functional blood vasculature. LYVE-1, lymphatic endothelial hyaluronan receptor-1, is the first indicator of lymphatic endothelial commitment, and is expressed in mice from embryonic day E9 in a polarized manner in the LECs differentiating in venous endothelium (Oliver 2004). It has been proposed that LYVE-1 expression in the embryonic cardinal veins signifies competence of the venous endothelium to receive an inductive signal that results in lymphatic endothelial cell fate specification (Wigle et al. 2002). In adults, LYVE-1 is downregulated in the collecting lymphatic vessels but remains high in lymphatic capillaries (Makinen et al. 2005). In addition to lymphatic endothelium, LYVE-1 is also expressed on blood vessels of the yolk sac and intra-embryonic arterial and venous endothelium at early embryonic stages, on endothelial cells of the lung and endocardium throughout embryogenesis, as well as in liver sinusoids (Gordon et al. 2008). LYVE-1 is thought to participate in hyaluronan transport and leukocyte migration across the lymphatic vessel wall (Jackson 2004). Lyve 1 ${ }^{-/-}$mice do not display lymphatic vascular defects, suggesting the existence of compensatory mechanisms (Gale et al. 2007).

The transcription factor prospero-related homeobox 1, PROX1, controls the initial steps of lymphangiogenesis and is the most specific lineage marker for lymphatic endothelium (reviewed in Oliver and Detmar 2002). Targeted inactivation of Proxl in mice leads to a complete absence of lymphatic vessels, while blood vasculature development proceeds normally (Wigle et al. 2002; Wigle and Oliver 1999). Around E9.5 of mouse development, polarized expression of PROX1 is observed on one side of the anterior cardinal veins and soon thereafter these cells start budding and migrating in a polarized manner, eventually forming lymph sacs. PROX1 acts as a master regulator of lymphatic endothelial differentiation, as in the absence of PROX1 endothelial cells continue to express blood vascular endothelial cell (BECs) markers, while the ectopic expression of PROX1 in human BECs induces expression 
of lymphatic-specific genes and suppresses many blood vascular-specific transcripts (Hong et al. 2002; Petrova et al. 2002; Wigle et al. 2002). At present, the signals that induce PROX1 expression in a restricted subpopulation of endothelial cells are not well understood. Interleukin (IL)-3 and IL-7 have been shown to induce PROX1 expression in human cultured BECs, but whether they provide signals for lymphatic differentiation in vivo has not yet been addressed (Al-Rawi et al. 2005; Groger et al. 2004). In addition, direct PROX1 target genes that mediate its function during the process of lymphangiogenesis are not known. In cultured endothelial cells, PROX1 has been shown to induce the expression of important genes regulating lymphatic development, such as vascular endothelial growth factor receptor-3 (VEGFR-3) (Petrova et al. 2002; Saharinen and Petrova 2004; Wigle et al. 2002) and integrin- $\alpha 9$ (Mishima et al. 2007) thereby promoting the migration of LECs towards the VEGFR-3 ligand, VEGF-C, and regulating the endothelial sheet formation (Mishima et al. 2007). PROX1 also regulates the expression of fibroblast growth factor receptor-3 (FGFR-3) in vitro (Shin et al. 2006), however, the role of FGFR-3 in lymphatic vascular development in vivo remains to be investigated.

\section{Lymphatic sprouting}

Endothelial receptor tyrosine kinase VEGFR-3 and its ligand VEGF-C are required for the survival, maintenance, and migration of lymphatic vessels during embryonic development (reviewed by Karpanen and Alitalo 2008; Tammela et al. 2005a) and a 2 week postnatal period, after which lymphatic vessels become independent of VEGFR-3 (Karpanen et al. 2006b). During early development, VEGFR-3 is expressed in all endothelial cells and is important for blood vascular remodeling (Dumont et al. 1998; Hamada et al. 2000), indeed Vegfr3-deficient mice die at E9.5 owing to cardiovascular failure. At the onset of lymphangiogenesis, VEGFR-3 expression becomes restricted to newly forming LECs (Dumont et al. 1998). However, VEGFR-3 is upregulated in the blood microvasculature of tumors (Valtola et al. 1999) and wounds (Paavonen et al. 2000). Moreover, VEGFR-3 is highly expressed in angiogenic sprouts and blocking of VEGFR-3 signaling results in decreased sprouting, vascular density, vessel branching and endothelial cell proliferation (Tammela et al. 2008). The two known ligands of VEGFR-3, VEGF-C, and VEGF-D, can induce lymphangiogenesis in vivo and stimulate proliferation, survival, and migration of LECs in vitro (Jeltsch et al. 1997; Mäkinen et al. 2001; Veikkola et al. 2001). VEGF-C is expressed by mesenchymal cells surrounding the cardinal veins, and is essential for the initial sprouting and directed migration as well as for the subsequent survival of LECs. Consequently, in the absence of Vegfc,
PROX $1^{+}$LECs arise normally in the embryonic veins, but are unable to sprout and migrate from their original location, and Vegfc deficient mice do not develop a lymphatic vasculature (Karkkainen et al. 2004). VEGF-D is dispensable for lymphatic vascular development, and Vegfd ${ }^{-1-}$ embryos display only mild hypoplasia of the pulmonary lymphatic vasculature, although exogenous VEGF-D protein rescues the impaired vessel sprouting in $V e g f c^{-l}$ embryos (Baldwin et al. 2005; Karkkainen et al. 2004).

After proteolytic cleavage, fully processed, mature forms of VEGF-C and VEGF-D serve as also ligands for the major regulator of angiogenesis, VEGFR-2 (Achen et al. 1998; Joukov et al. 1997). It has recently been suggested that cooperative signaling between VEGFR-2 and VEGFR-3 is required for LECs migration and proliferation, whereas VEGFR-3 is redundant with VEGFR-2 for the organization of LECs into functional capillaries (Goldman et al. 2007). However, when activated by overexpression of VEGF or the related VEGFR-2-specific ligand VEGF-E, VEGFR-2 signals only promote lymphatic vessel enlargement and are not involved in vessel sprouting to generate new lymphatic vessels in vivo (Wirzenius et al. 2007). Moreover, a mutant form of VEGF-C unable to stimulate VEGFR-2 is sufficient for stimulating lymphangiogenesis (Joukov et al. 1998; Veikkola et al. 2001).

The importance of VEGF-C/VEGFR-3 pathway for lymphatic vascular development has been recently highlighted by studies in zebrafish, which resolved a long standing controversy about the presence of lymphatic vessels in teleost fishes (Küchler et al. 2006; Vogel and Claviez 1981; Yaniv et al. 2006). Zebrafish lymphatic vessels express high levels of Proxl, Nrp2 (neuropilin-2), Vegfr3, and Angpt2 (angiopoietin-2) and, knock-down of Proxl and Vegfc or inhibition of VEGFR-3 signaling by expression of VEGF-C trap VEGFR-3-Ig fusion protein prevents the formation of lymphatic vasculature (Küchler et al. 2006; Yaniv et al. 2006). Use of zebrafish or Xenopus embryos as small vertebrate models offers unparalled opportunities for identification of novel regulators of lymphatic vascular development and detailed analysis using in vivo imaging approaches $(\mathrm{Ny}$ et al. 2005; Yaniv et al. 2006).

In addition to VEGF-C and VEGF-D, extracellular matrix proteins, collagen, and fibronectin, enhance tyrosine phosphorylation of VEGFR-3 through activation of integrin $\beta 1$, which interacts directly with VEGFR-3 (Wang et al. 2001). As mice deficient in both Vegfc and Vegfd, unlike Vegfr3 null mice, have normal blood vascular development (Haiko et al. 2008), it is likely that other VEGFR-3 ligands, such as integrins, contribute to VEGFR-3 signaling in blood vascular endothelium. Additional VEGF-C signal transduction pathways were also described, such as interaction of VEGF-C with neuropilin-2 (NP2) and integrin $\alpha 9$. Indeed, NP2 is cointernalized along with VEGFR-3 in the 
endocytic vesicles of lymphatic endothelial cells upon stimulation with VEGF-C or VEGF-D, suggesting that NP2 modulates VEGFR-3 signaling (Karpanen et al. 2006a). The formation of small lymphatic vessels and capillaries is abnormal in Nrp2 knockout mice, these vessels are absent or severely reduced until postnatal stages, whereas larger lymphatic vessels develop normally (Yuan et al. 2002). It may be significant that integrin $\alpha 9 \beta 1$ binds VEGF-C and VEGF-D, and endothelial adhesion to and migration on the lymphangiogenic vascular endothelial growth factors (VEGF-C and -D) are $\alpha 9 \beta 1$-dependent (Vlahakis et al. 2005). Mice deficient in the integrin $\alpha 9$ chain die of chylothorax during the early postnatal period, suggesting an underlying function for integrin $\alpha 9 \beta 1$ in the normal development of the lymphatic system, including the thoracic duct (Huang et al. 2000).

Several other growth factors with lymphangiogenic function have been proposed, including fibroblast growth factor-2 (FGF-2), platelet-derived growth factors (PDGFs), insulinlike growth factors (IGFs), hepatocyte growth factor (HGF) and growth hormone (GH) (Banziger-Tobler et al. 2008; Björndahl et al. 2005; Cao et al. 2004, 2006; Chang et al. 2004; Kajiya et al. 2005; Kubo et al. 2002; Saito et al. 2006; Shin et al. 2006). While all of them are capable of stimulating the proliferation of lymphatic endothelial cells in vitro or sometimes upon overexpression in vivo, their definitive role in developmental or pathological lymphangiogenesis via loss-of-function analysis remains to be established. Indirect lymphangiogenic effect in vivo, for example through an increased recruitment of VEGF-C/D expressing inflammatory cells, is a plausible alternative for FGF-2 and HGF action (Cao et al. 2006; Chang et al. 2004; Kubo et al. 2002).

\section{Separation of blood and lymphatic vasculature}

The primary lymphatic plexus, which begins to form in mice around E10.5-E11, is composed of capillary-like vessels and is initially connected to the blood vasculature. In adults, apart the lymphatico-venous communications in the renal, hepatic, and adrenal veins, and in the lymph nodes, the main connections of blood and lymphatic vasculature locate at the junction where thoracic and right lymphatic ducts empty their contents into the subclavian veins. This suggests that mechanisms exist for keeping the blood and lymphatic vascular compartments separate. Tyrosine kinase Syk and adaptor protein Slp76 are important for this separation (Abtahian et al. 2003; Sebzda et al. 2006), as deficiency in Syk or Slp76 results in arterio-venous shunting and mixing of blood and lymphatic endothelial cells, which ultimately leads to haemorrhaging and perinatal death. The model proposed is that the exit of progenitors from veins is defective, and this leads to the formation of lymphovenous connections. Syk and Slp76 are expressed almost exclu- sively in hematopoietic cells, suggesting a role for this cell type in regulating the separation of the blood and lymphatic vascular networks.

Fasting-induced adipose factor (Fiaf) (or angiopoietinlike protein 4 (Angptl4)) is another factor involved in the regulation of lymphatic and blood vessel separation in the intestine. Mice deficient in Fiaf developed normally until birth, but displayed blood-filled intestinal lymphatic vessels post-natally, and decreased Proxl expression was observed on the LYVE-1 ${ }^{+}$vessels in Fiaf ${ }^{-1}$ mice (Bäckhed et al. 2007). However, the underlying mechanisms, including the identification of the Fiaf receptor, remain to be investigated. This study suggests that active and organ-specific mechanisms are required after birth to preserve the separation of the blood and lymphatic vascular systems.

\section{Maturation of the lymphatic vasculature}

The primary lymphatic plexus undergoes a further dramatic change to form a hierarchically organized network of lymph vessels, composed of capillaries devoid of basement membrane and pericytes, and collecting lymphatic vessels containing intraluminal valves, basement membrane, and covered with SMCs. This complex process of reorganization of lymph vessels is referred as "lymphatic vascular maturation", during which new capillaries arise by sprouting from the pre-existing vasculature, SMCs on collecting vessels are recruited and luminal valves are formed. Angiopoietin-2, EphrinB2, FOXC2, and Podoplanin have been shown to play important roles at late steps of lymphatic vascular development.

Angiopoietins and Tie receptors are involved in the remodeling and stabilization of lymphatic vessels. Three members of the Angiopoietin family (Ang1, Ang2, and Ang3/4) are ligands for the Tie1 and/or Tie2 receptor tyrosine kinases, which are expressed both in blood vascular and lymphatic endothelia (Iljin et al. 2002; Morisada et al. 2005; Tammela et al. 2005b). Ang1 can activate both Tie1 and Tie2 that appear as preformed heteromeric complexes between the two receptor molecules (Saharinen et al. 2005). Overexpression of Angl in adult mice stimulates lymphatic endothelial cell proliferation and promotes vessel enlargement and generation of new sprouts (Morisada et al. 2005; Tammela et al. 2005b). Ang2 is required for postnatal blood vascular remodeling and proper development of the lymphatic vasculature. Angpt2-deficient mice display a disorganization and hyperplasia of the vessels caused by impaired recruitment of SMCs onto collecting lymphatic vessels and an irregularly patterned hypoplastic lymphatic capillary network. Interestingly, replacement of Ang2 by Ang1 was sufficient to rescue the lymphatic phenotype (Gale et al. 2002).

During vascular development, EphrinB2 plays important roles in the remodeling of the arterial-venous capillary 
plexus and in the postnatal maturation of the lymphatic vasculature. EphrinB2 is expressed in collecting lymphatic vessels, whereas its receptor EphB4 is detected both in collecting lymphatic vessels and in lymphatic capillaries. Mice lacking the PDZ interaction domain of EphrinB2, develop an apparently normal blood vasculature, but fail to establish a hierarchically organized lymphatic vessel network consisting of lymphatic capillaries and collecting vessels. These mutants display defects in the formation of luminal valves in the collecting vessels, ectopic SMC coverage in lymphatic capillaries, and persistent expression of LYVE-1 in all lymphatic vessels (Makinen et al. 2005).

FOXC2 is a forkhead transcription factor, which is involved in the specification of the lymphatic capillary versus collecting lymphatic vessel phenotype. This factor is highly expressed in the developing lymphatic vasculature and in the luminal valves in adult lymphatic vessels (Dagenais et al. 2004; Petrova et al. 2004). Initial development of the lymphatic vasculature proceeds normally in the absence of FOXC2; however, later the patterning of the lymphatic vasculature becomes abnormal. Collecting lymphatic vessels in $\mathrm{Foxc}^{-1-}$ mice fail to develop valves while the lymphatic capillaries acquire an excessive coverage by SMCs and components of the basal lamina, and begin to express some blood vascular endothelial cell markers such as Endoglin and PDGF-B (Petrova et al. 2004). Mice heterozygous for both Foxc2 and Vegfr3 display a phenotype very similar to $\mathrm{Foxc}^{-/-}$mice, suggesting that FOXC2 and VEGFR-3 act through a common genetic pathway to establish some of the distinct properties of the lymphatic vasculature. The human disease lymphedema-distichiasis (LD), an autosomal dominant disease, is caused by heterozygousloss-of-function mutations of Foxc2 (Fang et al. 2000). Unlike in congenital lymphedema, the lymphatic vasculature in LD is normal or hyperplastic, but there is lymph backflow, presumably due to abnormal lymphatic valves, defective patterning and the presence of ectopic SMCs (Brice et al. 2002; Petrova et al. 2004). Interestingly, a recent study showed that Foxc2 mutations are associated with primary venous valve failure in both the superficial and deep veins in the lower limb. Thus, this gene appears to be important for the normal development and maintenance of both venous and lymphatic valves (Mellor et al. 2007).

Podoplanin, a small transmembrane mucin-like protein, is highly expressed in lymphatic endothelial cells. In mice, its expression starts around E11 and remains high both in collecting lymphatic vessels and in lymphatic capillaries in the adult (Breiteneder-Geleff et al. 1999; Schacht et al. 2003). Pdpn-deficient mice die at birth due to abnormal lung development and have defects in lymphatic but not blood vessel formation and patterning, which result in impaired lymphatic transport, dilation of lymphatic vessels, and congenital lymphedema (Schacht et al. 2003). Podoplanin is upregulated in the invasive front of many human carcinomas and promotes collective cell migration by filopodia formation via the downregulation of the activities of small Rho family GTPases (Wicki et al. 2006). In contrast to the role in tumor cells, siRNA mediated knockdown of Podoplanin in lung LECs prevented activation of RhoA during capillary morphogenesis and impaired localization of phosphorylated ezrin/radixin/moesin proteins to plasma membrane (Navarro et al. 2008).

Other regulators of lymphatic vascular development

Spred-1 and Spred-2, two negative regulators for growth factor- and cytokine-induced ERK activation, were reported as mediators of the separation of lymphatic vessels from the parental vein, and Spred-1/Spred-2 double-knockout phenotype resembles that of Syk- and Slp-76-deficient mice. Spred proteins were shown to regulate VEGF-C signaling by suppressing VEGFR-3-mediated ERK and Akt activation (Taniguchi et al. 2007). However, the phenotype of Spred-1/Spred-2 knockout mice differs from the one observed in Vegfc knockout or Vegfr3 mutant Chy mice (Karkkainen et al. 2004), therefore alternative explanations should be also considered.

Adrenomedullin (AM), a vasodilatator and diuretic peptide, is necessary for murine lymphatic vascular development (Fritz-Six et al. 2008; Jin et al. 2008). Genetic loss of $\mathrm{AM}$ or components of its receptor complex, calcitonin receptor-like receptor and receptor activity-modifying protein 2 (RAMP2), leads to non-hemorrhagic edema and embryonic lethality at midgestation (Fritz-Six et al. 2008). The initial development of lymphatic vasculature was not affected; however, loss of AM signaling resulted in severely hypoplastic jugular lymph sacs while the development of retroperitoneal and skin lymphatic vessels was normal. Administration of AM was also shown to improve secondary lymphedema in mouse tail lymphedema model, and to promote lymphangiogenesis (Jin et al. 2008). Interestingly, in contrast to Fritz-Six et al., another study of RAMP2 deficient mice concluded that AM has blood vascular functions, such as regulation of vascular stability and permeability, and that embryos lacking AM signaling die due to leaky and unstable blood vessels (Ichikawa-Shindo et al. 2008), therefore further work may be necessary to reconcile these results and to unravel details of AM signaling in the vasculature during embryonic development.

Asppl (apoptosis stimulating protein of p53), an endothelial-specific gene functioning in mouse embryogenesis, was recently described as an important player in the lymphatic vessel assembly. Aspp1 ${ }^{-l-}$ mice showed a disorganized lymphatic plexus and impaired lymphatic drainage function in embryonic skin, whereas the lymphatic drainage defect was resolved in adults. Moreover, collecting lymphatic 
vessels of Aspp1 ${ }^{-1-}$ adult mice possess luminal valves. These results indicate that Aspp1 is important for the initial assembly of lymphatic endothelial cells but dispensable for lymphatic remodeling (Hirashima et al. 2008). The lymphatic vascular function of Aspp1 is independent of p53, and may be linked instead to C-terminal Src kinase (Csk), given the fact the Drosophila homologue of Aspp1 acts as a positive regulator of dCsk in the control of epithelial integrity (Langton et al. 2007).

Recently, Sphingosine-1-phosphate (S1P), a potent bioactive lipid that is implicated in a variety of biologic processes such as inflammatory responses and angiogenesis, was reported as a lymphangiogenic mediator (Yoon et al. 2008). S1P induces the migration and capillary-like tube formation of lymphatic endothelial cells in vitro and lymphangiogenesis in vivo. Furthermore, the use of pertussis toxin, intracellular $\mathrm{Ca}^{2+}$ chelator, and phospholipase $\mathrm{C}$ (PLC) inhibitor efficiently blocks S1P-induced in vitro lymphangiogenesis and intracellular $\mathrm{Ca}^{2+}$ mobilization of HLECs, suggesting that S1P promotes lymphangiogenesis by stimulating $\mathrm{S} 1 \mathrm{P} 1 / \mathrm{Gi} /$ phospholipase $\mathrm{C} / \mathrm{Ca}^{2+}$ signaling pathways.

TGF- $\beta$ signaling negatively regulates lymphangiogenesis in inflammatory tissues as well as in certain tumor tissues. In addition to inhibiting the proliferation and migration of human dermal lymphatic microvascular endothelial cells, TGF- $\beta$ decreases the expression of LECrelated genes, including Proxl and Lyvel, in these cells. Moreover, TGF $\beta$ R-I inhibitor potentiates lymphangiogenesis in the presence of VEGF-C in vivo (Oka et al. 2008).

Finally, Emilin1, an elastic microfibril-associated protein, is expressed in lymphatic endothelial cells, and plays a role in the regulation of lymphatic vessel patterning and proliferation (Danussi et al. 2008). Emilin1 ${ }^{-1}$ mice have hyperplastic and disorganised lymphatic vessels with reduced number of anchoring filaments, and they also show impaired lymphatic drainage function. These data highlight the importance of interactions between LECs and surrounding ECM (Danussi et al. 2008).

\section{Pathology of lymphatic vessels}

The lymphatic vascular system is a dynamic structure that responds to a changing environment and evolves during the life of individual. In the adult, many pathological conditions affect the lymphatic vessels and they respond by undergoing neo-lymphangiogenesis. Such events include inflammation and immune responses, tumorigenesis and after trauma, infections, surgery and radiation. Many of the known regulators of developmental lymphangiogenesis have also been implicated in neo-lymphangiogenesis and pathological conditions.
Lymphedema

Congenital or acquired dysfunction of the lymphatic system can result in the formation of lymphedema, due to the stagnation of lymph and accumulation of tissue fluid because of an impairment of the capacity to remove fluid from the interstitium (Fig. 2a). This may be caused by abnormal lymphatic vessel development or damaged lymphatic vessels. Lymphedema is a progressive disease characterized by swelling of the affected limb, accompanied by fibrosis, fatty degeneration of the connective tissue and susceptibility to infections (reviewed by Rockson 2001). The treatment of lymphedema is currently based on manual lymphatic drainage by physiotherapy, compression garments, and occasionally surgery. Lymphedema is usually divided into two main categories. Primary lymphedema is a condition with no identifiable antecedent cause that can be present at birth (congenital), at puberty (praecox) or, more rarely, at adulthood (tarda). Secondary, acquired lymphedema develops when the lymphatic vessels are damaged by infection, for example as a result of parasitic infection (filiariasis), radiation therapy, or when lymph nodes are surgically removed.

Milroy's disease or primary congenital lymphedema (Online Mendelian Inheritance in Man, OMIM, number 153100), becomes apparent at birth, affects primarily the legs and feet and is characterized by an absence or reduced number of lymphatic vessels (Brice et al. 2005). This disease has been associated with missense mutations encoding inactive tyrosine kinase VEGFR-3 proteins (Butler et al. 2007; Irrthum et al. 2000; Karkkainen et al. 2000). Mutations in Vegfr3 were identified in mutant mouse strain Chy, which has defective lymphatic vessels (Karkkainen et al. 2001). This model has been used to test VEGF-C gene therapy, which promoted the formation of functional lymphatic vessels in these mice. In the case of lymphedema-distichiasis (LD, OMIM 153400), mutations in the forkhead transcription factor FOXC2 have been identified (Fang et al. 2000; Finegold et al. 2001). This disorder is characterized by distichiasis (a double row of eyelashes) at birth and bilateral lower limb lymphedema at puberty. LD is associated with abnormal lymph vessel patterning, agenesis of lymphatic valves, and abnormal recruitment of SMCs (Petrova et al. 2004). Generated Foxc2 $2^{ \pm}$and Foxc2 $2^{-l-}$ mice constitute useful animal models for this disorder (Kriederman et al. 2003; Petrova et al. 2004). A recent study reported renal disease and diabetes mellitus in combination with LD caused by a Foxc 2 mutation, reflecting the developmental role of FOXC2 in multiple tissues (YildirimToruner et al. 2004). Finally, mutations in the transcription factor SOX18 were recently identified in recessive and dominant forms of hypotrichosis-lymphedema-telangiectasia (Irrthum et al. 2003). 

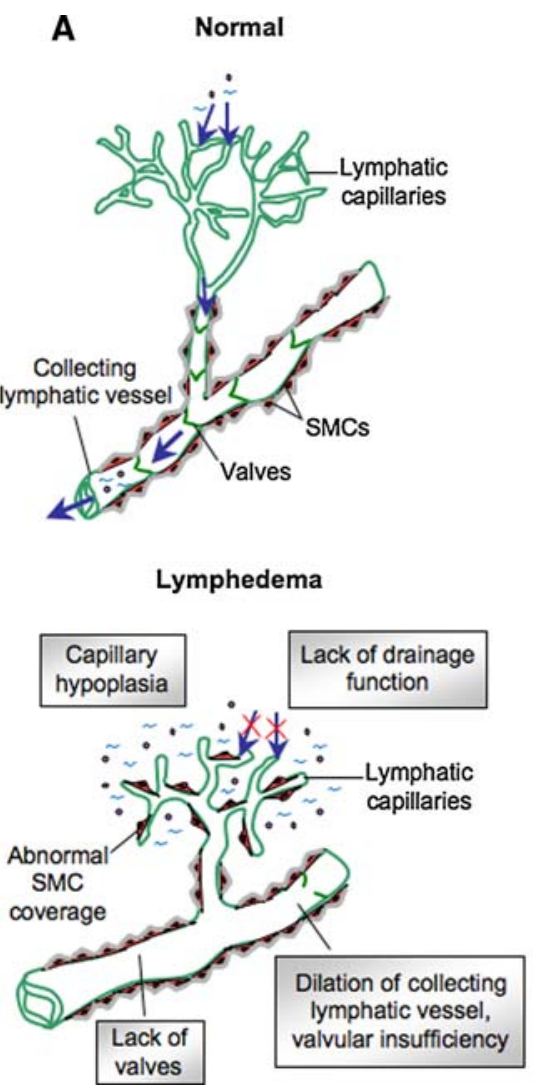

Fig. 2 Lymphatic vasculature in disease. a Malformation of lymphatic capillaries, damage to collecting lymphatic vessels and lack or insufficient function of lymphatic valves can lead to lymphedema. Abnormal coverage by smooth muscle cells (SMC), observed in some lymphedema patients, may also compromise the function of lymphatic capillaries and leads to insufficient lymph drainage. b Inflammatory cells produce proinflammatory cytokines and lymphangiogenic factors that stimulate lymphatic vessel growth. Lymphatic endotheial cells produce CCL21, which further attracts $\mathrm{CCR}^{+}$lymphocytes and dendritic cells. VEGF-A is prominently expressed by follicular B cells and

Edema of the arm after axillary lymph node dissection is probably the most common cause of lymphedema in industrialized countries. The reported incidence of edema after mastectomy, approximately $6-30 \%$ of operated patients, is increased by radiotherapy, but its etiology and pathophysiology are still not fully understood and appear to be multifactorial (reviewed by Rockson 2001). A recent study, using a newly established axillary lymphadenectomy mouse model, showed that collecting lymphatic vessels can be regenerated and fused to lymph node transplants after lymph node removal. Treatment with adenovirally delivered VEGF-C or VEGF-D induces robust growth of the lymphatic capillaries, which can mature and become functional even without the presence of lymph nodes. Furthermore, VEGF-C therapy greatly improves the success of lymph node survival; without VEGF-C the transplantation leads to atrophy of lymph node structure. Combination of is a potential mediator of the increase in lymphatic vessels and DC migration in inflamed lymph nodes. c Tumor and tumor-associated macrophages secrete factors, such as VEGF-C and VEGF-D, which can induce lymphatic vessel growth in the periphery of and/or inside the tumor as well as in the draining sentinel lymph nodes. The lymphatic endothelial cells may also actively attract some tumor cells through the secretion of chemokines, such as CCL21. Tumor-associated and lymph node lymphangiogenesis can lead to enhanced metastasis to sentinel lymph nodes and beyond to distant organs

VEGF-C therapy and lymph node transplantation thus provides a working model for treating individuals with a history of cancer (Tammela et al. 2007).

Worldwide, the main cause of lymphedema is filariasis, in over 80 tropical and subtropical countries, with about 120 million people affected (Wynd et al. 2007). This disease is caused by infection with the mosquito-borne parasites Wuchereria bancrofti and Brugia malayi, which live and reproduce in the lymphatic system. This leads to a massive damage of lymphatic vessels with a complete and permanent disruption of lymphatic transport, resulting in chronic lymphedema of the legs and genitals (reviewed by Melrose 2002). Current drugs (diethylcarbamazine or ivermectin, usually given with albendazole) effectively killed the microfilariae (larval offspring of the parasite), but their effect on the macrofilariae (adult worms) was incomplete. Doxycycline was suggested as a novel strategy against 
bancroftian filariasis. This drug depletes Wolbachia, the intracellular bacterial symbiont of filarial parasites, and kills most adult worms (Hoerauf et al. 2003; Stolk et al. 2005).

\section{Inflammation}

Inflammation and immune system dysfunction are intimately associated with increased lymphangiogenesis. VEGF-C is upregulated in response to proinflammatory cytokines, presumably through NF- $\kappa \mathrm{B}$-mediated promoter activation, suggesting a role for the regulation of lymphatic vessel growth during inflammation (Ristimaki et al. 1998). Interestingly, $\mathrm{NF}-\kappa \mathrm{B}$ is also constitutively active in at least some lymphatic vessels (Saban et al. 2004). Lymphatic vessels actively regulate inflammatory responses by transporting leukocytes from the site of inflammation to secondary lymphoid organs (Fig. 2b). Upon exposure to an inflammatory stimulus and recognition of pathogen-associated molecular patterns, dendritic cells (DC) capture antigens in peripheral tissues and migrate through afferent lymphatic vessels into lymph nodes. After their maturation, DC express higher levels of the specific lymphoid chemokine receptor CCR7 (Sallusto et al. 1998) that promotes their migration into lymph node, attracted by the ligand of CCR7, the chemokine CCL21 (or SLC, Secondary Lymphoid tissue Chemokine) produced by the lymphatic vascular endothelium of afferent vessels (Ohl et al. 2004; Saeki et al. 1999; Sallusto et al. 1998). Antigenic peptide-loaded DC are transported by lymph to the subcapsular sinus and enter the paracortex zone where they aggregate preferentially around high endothelial venules (HEV), on the entry route of $\mathrm{T}$ cells into the paracortex, and thus may foster the presentation of major histocompatibility complex (MHC)peptide complexes to passing $\mathrm{T}$ cells and optimize initial $\mathrm{T}$ cell activation (Bajenoff et al. 2003). In addition, native antigen-loaded DC could encounter B cells that enter the lymph node by HEV and activate them (Qi et al. 2006). Other cell types are also transported by afferent vessels, such as $\mathrm{T}$ and $\mathrm{B}$ lymphocytes and macrophages (Mackay et al. 1988). Indeed DC, T, and B cells leave peripheral tissues and migrate towards lymph nodes owing to their expression of chemokine receptor CCR7 (Bromley et al. 2005; Debes et al. 2005). Additional mechanisms that could also control this afflux of lymphocytes include interactions of lymphocytes with adhesion molecules expressed by lymphatic endothelium as CLEVER-1 (Common Lymphatic Endothelial and Vascular Receptor-1) (Salmi et al. 2004) and Mannose receptor 1 (Irjala et al. 2001). Finally, naive T and B cells, which have failed to find their specific antigen, or activated $\mathrm{T}$ cells, will go through medullary cords before reaching efferent vessels, and then return to bloodstream. Exit of lymphocytes depends on the expression of a G protein coupled receptor, Sphingosine-1-phosphate 1 (S1P1) by lymphatic endothelial cells and its ligand S1P expressed by lymphocytes (Mandala et al. 2002; Matloubian et al. 2004). Immunisation leads to enhanced lymph node lymphangiogenesis, an event that in turn leads to improved DC mobilisation. Of particular note, lymphangiogenesis occurred not only at the infection site and the draining lymph node, but also in uninvolved peripheral tissue that drains to the same lymph node. VEGF-A, ligand of VEGFR-2, which is highly expressed by follicular B cells, is a possible mediator of the increase lymphangiogenesis and DC migration (Angeli et al. 2006).

Macrophages are suggested to have a dual role in inflammation-induced lymphangiogenesis (Kerjaschki 2005). Macrophages recruited into the inflammation site can transform from naive monocytes into VEGF-C/D-producing cells, which can stimulate the growth of existing LECs (Schoppmann et al. 2002). They might also contribute to lymphangiogenesis by trans-differentiating to lymphatic endothelial cells, which incorporate into the lymphatic endothelium (Maruyama et al. 2005). Furthermore, human kidney transplant rejection is frequently accompanied by lymphangiogenesis, and these lymph vessels produced CCL21, which further attracted CCR $7^{+}$lymphocytes and $\mathrm{DC}$, and might actively promote the inflammatory process (Kerjaschki et al. 2004). In addition, other inflammatory diseases seem to be associated with lymphatic activation and dysfunction. For example, lymphatic hyperplasia is observed in UVB-irradiation-induced skin inflammation, in a mouse model of chronic skin inflammation resembling psoriasis, and in human psoriatic skin lesions (Kajiya et al. 2006; Kunstfeld et al. 2004). In chronic airway inflammation induced by Mycoplasma pulmonis, a massive lymphangiogenesis is induced by VEGF-C/-D-producing inflammatory cells, and its blocking resulted in bronchial lymphedema, thus demonstrating the importance of lymphangiogenesis for compensation of vascular leakage during the inflammation (Baluk et al. 2005). Finally, the role of VEGF-C/D-VEGFR-3 signaling in inflammatory lymphangiogenesis is also suggested by overexpression of VEGF-C in the joint synovium of rheumatoid arthritis patients (Paavonen et al. 2002). These studies underline the close relationship between inflammation, the immune response and the adaptability of a mature lymphatic network.

\section{Tumor lymphangiogenesis}

Tumor metastasis to regional lymph nodes often represents the first step of tumor dissemination and serves as a major prognostic indicator for the progression of human cancers. A variety of mechanisms may contribute to the dissemination of primary malignant cancer cells: local tissue invasion, systemic metastasis via tumor-associated blood vessels to distant organs, and lymphatic metastasis via 
tumor-associated lymphatic vessels to the draining (sentinel) lymph node, distal lymph nodes, and from there to distal organs. The latter pathway constitutes the most common pathway of initial metastasis for many types of solid human tumors (reviewed by Stacker et al. 2002b). The extent of lymph node metastasis is a major determinant for the staging and the prognosis of most human malignancies and often guides therapeutic decisions. Despite this, the molecular mechanisms of lymphatic metastasis are not completely understood.

Dissemination of tumor cells from the primary sites to the lymphatic system is accomplished either by invasion into pre-existing lymphatic vessels in the surrounding tissues or by invasion into intratumoral lymphatic networks (Achen et al. 2005; Alitalo et al. 2004; Cao et al. 2004; Cao 2005; Karpanen et al. 2001; Mandriota et al. 2001; Skobe et al. 2001; Stacker et al. 2001a). In some cases of human cancers the presence of lymphatic vessels inside the tumor was reported to correlate positively with lymph node metastasis and poor prognosis (Beasley et al. 2002; Kyzas et al. 2005). However, the issue whether intratumoral lymphatic vessels are important for tumor spread is controversial; indeed, intratumoral lymphatic vessels might be poorly functional and not required for lymphatic metastasis (Padera et al. 2002; Wong et al. 2005). In contrast to intratumoral vessels, peritumoral lymphatic vessels certainly are functional and have a drainage function (He et al. 2002, 2004; Padera et al. 2002). In addition, tumor cells produce lymphangiogenic factors that could dilate the pre-existing lymphatic vessels surrounding the tumor tissue. Some of these factors are able to facilitate the transmigration of tumor cells through the lymphatic endothelium (Alitalo et al. 2004).

Tumor cells and tumor-associated macrophages can express lymphangiogenic factors VEGF-C and VEGF-D, thus they could play a role in peritumoral lymphangiogenesis and subsequent dissemination in human cancer (Schoppmann et al. 2002) (Fig. 2c). Studies in animal tumor models have provided direct experimental evidence that increased levels of VEGF-C or VEGF-D promote active tumor lymphangiogenesis and lymphatic tumor spread to regional lymph nodes (Karpanen et al. 2001; Mandriota et al. 2001; Skobe et al. 2001; Stacker et al. 2001b). These effects are suppressed by specific inhibition of the VEGFR-3 pathway-using either blocking VEGFR3 antibody, VEGF-C/D trap (VEGFR-3 extracellular domain fused with immunoglobulin Fc portion) or VEGFC targeting siRNA - that prevents cancer metastasis to lymph nodes and beyond (e.g. (He et al. 2002; Karpanen et al. 2001; Lin et al. 2005; Roberts et al. 2006), underlining the direct link between VEGF-C or VEGF-D expression and metastasis. Moreover, a large number of clinicopathological studies of human cancers have shown a direct correlation between expression of VEGF-C or
VEGF-D by tumor cells and lymphatic invasion, lymph node and distant metastasis, and poor patient survival, but not necessarily with the density of tumor-associated lymphatic vessels (Achen et al. 2005; Pepper et al. 2003; Stacker et al. 2002a; Tobler and Detmar 2006). Combination of siRNA therapy targeting both VEGF-C and VEGFA inhibits both lymph node and lung metastasis in a mouse immunocompetent mammary cancer model, rendering this combined therapy more beneficial than either alone (Shibata et al. 2008).

VEGF-C stimulates the growth of new tumor-associated lymphatic vessels, and in this process nearby LECs send filopodia toward VEGF-C producing tumor cells, and then form tumor-directed vessel sprouts, where the vessel lumen opens up and allows facilitated access of tumor cells to the lumen (He et al. 2005). The lymphatic endothelium may also actively participate in metastasis formation by secreting chemokines such as CCL21, whose receptor is expressed on some malignant cells (Shields et al. 2006; Zlotnik 2004). Moreover, intraluminal VEGF-C also promotes the dilation of collecting lymphatic vessels through the process of endothelial proliferation in the vessel wall, and further enhances the delivery of tumor cells to sentinel lymph nodes, probably by increasing the lymph flow rate (He et al. 2005; Hoshida et al. 2006).

Overexpression of VEGF-C or VEGF-A under the control of keratinocyte-specific promoter can induce active proliferation of tumor-associated lymphatic vessels in a multi-step skin carcinogenesis model, leading to enhanced tumor metastasis to the sentinel and distant lymph nodes (Hirakawa et al. 2005, 2007). This effect is preceded by lymphangiogenesis in sentinel lymph nodes, which suggests that primary tumors can prepare their future metastatic site in advance of their arrival, partly by producing lymphangiogenic factors. Induction of lymph node lymphangiogenesis and increased lymph flow through tumor-draining lymph nodes, prior to tumor cell arrival, was suggested to be B celldependent (Harrell et al. 2007). In addition, not only can cancer cells 'prepare the ground' for metastasis, but also stromal cells might serve as important mediators for tumorinduced lymphangiogenesis. A recent study, using a conditional transgenic mouse model of breast cancer, showed that hyaluronan-rich tumor microenvironment plays an important role in promoting tumor lymphangiogenesis, thus demonstrating the importance of the tumor stromal cells and extracellular matrix in educating malignant cells to secrete specific lymphangiogenic factors (Koyama et al. 2008).

\section{Concluding remarks}

In recent years, novel molecules regulating the development, differentiation, morphogenesis and functional expression 
of lymphatic endothelial cells have been successively identified, resulting in marked advances in the field of lymphangiogenesis. Progress in technical tools such as sophisticated animal models, better imaging techniques that allow work at cellular or subcellular resolution and in live animals during dynamic studies and high throughput genomic or proteomic screens, have made vascular morphogenesis much more accessible to research. However, many questions concerning some fundamental processes of physiological and pathological lymphangiogenesis are yet remain unresolved.

Early steps of lymphatic endothelial cell commitment are not yet completely understood, and the mechanisms of lymphatic vascular remodeling and maturation are only beginning to be elucidated. It will be important to clarify the importance of mesenchymal lymphangioblasts as a secondary source of LECs, other than the venous endothelium. Furthermore, signals that induce PROX1 expression in a restricted subpopulation of endothelial cells and direct PROX1 target genes that act as its effectors in lymphatic endothelium remain to be identified. Lymphangiogenesis bears a close resemblance to angiogenesis, yet it appears that lymphatic vasculature uses distinct molecular mechanisms. It will be important to understand the basis for such differences and identify signaling pathways that control different stages of lymphatic vascular development. Further studies are needed to pinpoint the mechanisms that keep the emerging lymphatic vessels separate from blood vessels. This process appears to be complex and it is likely that includes other factors in addition to Syk/Slp76. Furthermore, the lymphatic vascular tree is composed of a system of lymphatic vessels of different size and morphology; it would be interesting to study the phenotypic and genotypic differences of the LECs that comprise these vessels, and to characterize endothelial, molecular, and phenotypic variability through the lymphatic vasculature system.

Answers to these questions will help to provide a comprehensive picture of lymphatic vascular development, and will contribute to our understanding of the mechanisms involved in lymphatic vascular dysfunction in lymphedema, inflammation, and cancer. In the case of lymphedema-distichiasis, it is necessary to extend the study of the role of FOXC2, and to identify direct FOXC2 target genes to enhance our understanding of the morphogenesis and differentiation of intraluminal valves.

The involvement of lymphatic vessels in inflammation should be explored in several contexts, and the impact of inflammation on the phenotype and function of lymphatic vessels needs to be investigated. In this way, a clear vision of physiological and ectopic lymph node neogenesis should provide information about the link between lymphatic vessels and lymph nodes. Finally, it is of great importance to have a better understanding of the importance of tumor- associated lymphangiogenesis in the spread of cancer to distant organs. The elucidation of the molecular mechanisms of lymphatic metastasis represents another challenge that will be instrumental in our understanding of how to control the spread of cancers in patients. It has become evident over the last decade that VEGFR-3 and its ligands VEGF-C and VEGF-D are critical targets for new drug development. The question now concerns the potential efficacy of targeting such lymphangiogenic growth factors in the management of cancer. In addition, the involvement of tumor microenvironment in neo-lymphangiogenesis has to be addressed, and with this the identification of stromal and immune determinants. That also implies studying the interactions between stromal cells and LECs, which could promote further development of lymphatic vessels. Immune cells have been shown to participate in tumor progression, and tumor immunomodulation could also form a part along with lymphangiogenic growth factor signaling, of processes that promote metastasis through the lymphatic system. The challenge for future studies is to identify new molecular and cellular players and increase our understanding of the basic biology of lymphatic development, which will contribute to designing novel therapeutic strategies for treatment of different lymphatic disorders.

Acknowledgments We extend our gratitude to the many colleagues who have contributed to the field, but whose work could not be cited here due to space limitations. We thank Alun Parsons for assistance in editing. The work in the authors' laboratory is supported by the Swiss National Science Foundation, the Academy of Finland, the Sigrid Juselius Foundation the Finnish Cancer Organizations, and the Association for the International Cancer Research.

Open Access This article is distributed under the terms of the Creative Commons Attribution Noncommercial License which permits any noncommercial use, distribution, and reproduction in any medium, provided the original author(s) and source are credited.

\section{References}

Abtahian F, Guerriero A, Sebzda E, Lu M-M, Zhou R, Mocsai A, Myers EE, Huang B, Jackson DG, Ferrari VA, Tybulewicz V, Lowell CA, Lepore JJ, Koretzky GA, Kahn ML (2003) Regulation of blood and lymphatic vascular separation by signaling proteins SLP-76 and Syk. Science 299:247-251

Achen MG, Jeltsch M, Kukk E, Mäkinen T, Vitali A, Wilks AF, Alitalo K, Stacker SA (1998) Vascular endothelial growth factor D (VEGF$\mathrm{D})$ is a ligand for the tyrosine kinases VEGF receptor 2 (Flk1) and VEGF receptor 3 (Flt4). Proc Natl Acad Sci USA 95:548-553

Achen MG, McColl BK, Stacker SA (2005) Focus on lymphangiogenesis in tumor metastasis. Cancer Cell 7:121-127

Adams RH, Alitalo K (2007) Molecular regulation of angiogenesis and lymphangiogenesis. Nat Rev Mol Cell Biol 8:464-478

Alitalo K, Mohla S, Ruoslahti E (2004) Lymphangiogenesis and cancer: meeting report. Cancer Res 64:9225-9229

Al-Rawi MA, Watkins G, Mansel RE, Jiang WG (2005) The effects of interleukin-7 on the lymphangiogenic properties of human endothelial cells. Int J Oncol 27:721-730 
Angeli V, Ginhoux F, Llodrà J, Quemeneur L, Frenette PS, Skobe M, Jessberger R, Merad M, Randolph GJ (2006) B cell-driven lymphangiogenesis in inflamed lymph nodes enhances dendritic cell mobilization. Immunity 24:203-215

Asellius G (1627) De lactibus sive lacteis venis. Mediolani, Milan

Bäckhed F, Crawford PA, O'Donnell D, Gordon JI (2007) Postnatal lymphatic partitioning from the blood vasculature in the small intestine requires fasting-induced adipose factor. Proc Natl Acad Sci USA 104:606-611

Bajenoff M, Granjeaud S, Guerder S (2003) The strategy of T cell antigen-presenting cell encounter in antigen-draining lymph nodes revealed by imaging of initial $\mathrm{T}$ cell activation. J Exp Med 198:715-724

Baldwin ME, Halford MM, Roufail S, Williams RA, Hibbs ML, Grail D, Kubo H, Stacker SA, Achen MG (2005) Vascular endothelial growth factor $\mathrm{d}$ is dispensable for development of the lymphatic system. Mol Cell Biol 25:2441-2449

Baluk P, Tammela T, Ator E, Lyubynska N, Achen MG, Hicklin DJ, Jeltsch M, Petrova TV, Pytowski B, Stacker SA, Ylä-Herttuala S, Jackson DG, Alitalo K, McDonald DM (2005) Pathogenesis of persistent lymphatic vessel hyperplasia in chronic airway inflammation. J Clin Invest 115:247-257

Baluk P, Fuxe J, Hashizume H, Romano T, Lashnits E, Butz S, Vestweber D, Corada M, Molendini C, Dejana E, McDonald DM (2007) Functionally specialized junctions between endothelial cells of lymphatic vessels. J Exp Med 204:2349-2362

Banziger-Tobler NE, Halin C, Kajiya K, Detmar M (2008) Growth hormone promotes lymphangiogenesis. Am J Pathol 173:586-597

Beasley NJP, Prevo R, Banerji S, Leek RD, Moore J, van Trappen P, Cox G, Harris AL, Jackson DG (2002) Intratumoral lymphangiogenesis and lymph node metastasis in head and neck cancer. Cancer Res 62:1315-1320

Björndahl M, Cao R, Nissen LJ, Clasper S, Johnson LA, Xue Y, Zhou Z, Jackson D, Jon Hansen A, Cao Y (2005) Insulin-like growth factors 1 and 2 induce lymphangiogenesis in vivo. Proc Natl Acad Sci USA 102:15593-15598

Breiteneder-Geleff S, Soleiman A, Kowalski H, Horvat R, Amann G, Kriehuber E, Diem K, Weninger W, Tschachler E, Alitalo K, Kerjaschki D (1999) Angiosarcomas express mixed endothelial phenotypes of blood and lymphatic capillaries: podoplanin as a specific marker for lymphatic endothelium. Am J Pathol 154:385-394

Brice G, Mansour S, Bell R, Collin JRO, Child AH, Brady AF, Sarfarazi M, Burnand KG, Jeffery S, Mortimer P, Murday VA (2002) Analysis of the phenotypic abnormalities in lymphoedema-distichiasis syndrome in 74 patients with FOXC2 mutations or linkage to 16q24. J Med Genet 39:478-483

Brice G, Child AH, Evans A, Bell R, Mansour S, Burnand K, Sarfarazi M, Jeffery S, Mortimer P (2005) Milroy disease and the VEGFR3 mutation phenotype. J Med Genet 42:98-102

Bromley SK, Thomas SY, Luster AD (2005) Chemokine receptor CCR7 guides $\mathrm{T}$ cell exit from peripheral tissues and entry into afferent lymphatics. Nat Immunol 6:895-901

Butler MG, Dagenais SL, Rockson SG, Glover TW (2007) A novel VEGFR3 mutation causes Milroy disease. Am J Med Genet A 143A:1212-1217

Buttler K, Kreysing A, von Kaisenberg CS, Schweigerer L, Gale N, Papoutsi M, Wilting J (2006) Mesenchymal cells with leukocyte and lymphendothelial characteristics in murine embryos. Dev Dyn 235:1554-1562

Buttler K, Ezaki T, Wilting J (2008a) Proliferating mesodermal cells in murine embryos exhibiting macrophage and lymphendothelial characteristics. BMC Dev Biol 8:43

Buttler K, Ezaki T, Wilting J (2008b) Proliferating mesodermal cells in murine embryos exhibiting macrophage and lymphendothelial characteristics. BMC Dev Biol 8:43
Cao Y (2005) Emerging mechanisms of tumour lymphangiogenesis and lymphatic metastasis. Nat Rev Cancer 5:735-743

Cao R, Björndahl MA, Religa P, Clasper S, Garvin S, Galter D, Meister B, Ikomi F, Tritsaris K, Dissing S, Ohhashi T, Jackson DG, Cao Y (2004) PDGF-BB induces intratumoral lymphangiogenesis and promotes lymphatic metastasis. Cancer Cell 6:333-345

Cao R, Bjorndahl MA, Gallego MI, Chen S, Religa P, Hansen AJ, Cao Y (2006) Hepatocyte growth factor is a lymphangiogenic factor with an indirect mechanism of action. Blood 107:3531-3536

Casley-Smith J (1980) The fine structure and functioning of tissue channels and lymphatics. Lymphology 13:177-183

Chang LK, Garcia-Cardeña G, Farnebo F, Fannon M, Chen EJ, Butterfield C, Moses MA, Mulligan RC, Folkman J, Kaipainen A (2004) Dose-dependent response of FGF-2 for lymphangiogenesis. Proc Natl Acad Sci USA 101:11658-11663

Dagenais SL, Hartsough RL, Erickson RP, Witte MH, Butler MG, Glover TW (2004) Foxc2 is expressed in developing lymphatic vessels and other tissues associated with lymphedema-distichiasis syndrome. Gene Expr Patterns 4:611-619

Danussi C, Spessotto P, Petrucco A, Wassermann B, Sabatelli P, Montesi M, Doliana R, Bressan GM, Colombatti A (2008) Emilin1 deficiency causes structural and functional defects of lymphatic vasculature. Mol Cell Biol 28:4026-4039

Debes GF, Arnold CN, Young AJ, Krautwald S, Lipp M, Hay JB, Butcher EC (2005) Chemokine receptor CCR7 required for T lymphocyte exit from peripheral tissues. Nat Immunol 6:889-894

Dumont DJ, Jussila L, Taipale J, Lymboussaki A, Mustonen T, Pajusola K, Breitman M, Alitalo K (1998) Cardiovascular failure in mouse embryos deficient in VEGF receptor-3. Science 282:946949

Fang J, Dagenais SL, Erickson RP, Arlt MF, Glynn MW, Gorski JL, Seaver LH, Glover TW (2000) Mutations in FOXC2 (MFH-1), a forkhead family transcription factor, are responsible for the hereditary lymphedema-distichiasis syndrome. Am J Hum Genet 67:1382-1388

Finegold DN, Kimak MA, Lawrence EC, Levinson KL, Cherniske EM, Pober BR, Dunlap JW, Ferrell RE (2001) Truncating mutations in FOXC2 cause multiple lymphedema syndromes. Hum Mol Genet 10:1185-1189

Fritz-Six KL, Dunworth WP, Li M, Caron KM (2008) Adrenomedullin signaling is necessary for murine lymphatic vascular development. J Clin Invest 118:40-50

Gale NW, Thurston G, Hackett SF, Renard R, Wang Q, McClain J, Martin C, Witte C, Witte MH, Jackson D, Suri C, Campochiaro PA, Wiegand SJ, Yancopoulos GD (2002) Angiopoietin-2 Is Required for Postnatal Angiogenesis and Lymphatic Patterning, and Only the Latter Role Is Rescued by Angiopoietin-1. Dev Cell 3:411-423

Gale NW, Prevo R, Espinosa J, Ferguson DJ, Dominguez MG, Yancopoulos GD, Thurston G, Jackson DG (2007) Normal lymphatic development and function in mice deficient for the lymphatic hyaluronan receptor LYVE-1. Mol Cell Biol 27:595-604

Gerli R, Ibba L, Fruschelli C (1991) Ultrastructural cytochemistry of anchoring filaments of human lymphatic capillaries and their relation to elastic fibers. Lymphology 24:105-112

Gerli R, Solito R, Weber E, Aglianó M (2000) Specific adhesion molecules bind anchoring filaments and endothelial cells in human skin initial lymphatics. Lymphology 33:148-157

Goldman J, Rutkowski JM, Shields JD, Pasquier MC, Cui Y, Schmokel HG, Willey S, Hicklin DJ, Pytowski B, Swartz MA (2007) Cooperative and redundant roles of VEGFR-2 and VEGFR-3 signaling in adult lymphangiogenesis. FASEB J 21:1003-1012

Gordon EJ, Gale NW, Harvey NL (2008) Expression of the hyaluronan receptor LYVE-1 is not restricted to the lymphatic vasculature; LYVE-1 is also expressed on embryonic blood vessels. Dev Dyn 237:1901-1909 
Groger M, Loewe R, Holnthoner W, Embacher R, Pillinger M, Herron GS, Wolff K, Petzelbauer P (2004) IL-3 Induces expression of lymphatic markers Prox-1 and pdoplanin in human endothelial cells. J Immunol 173:7161-7169

Grunewald M, Avraham I, Dor Y, Bachar-Lustig E, Itin A, Jung S, Chimenti S, Landsman L, Abramovitch R, Keshet E (2006) VEGF-induced adult neovascularization: recruitment, retention, and role of accessory cells. Cell 124:175-189

Haiko P, Makinen T, Keskitalo S, Taipale J, Karkkainen MJ, Baldwin ME, Stacker SA, Achen MG, Alitalo K (2008) Deletion of vascular endothelial growth factor C (VEGF-C) and VEGF-D is not equivalent to VEGF receptor 3 deletion in mouse embryos. Mol Cell Biol 28:4843-4850

Hamada K, Oike Y, Takakura N, Ito Y, Jussila L, Dumont DJ, Alitalo K, Suda T (2000) VEGF-C signaling pathways through VEGFR2 and VEGFR-3 in vasculoangiogenesis and hematopoiesis. Blood 96:3793-3800

Harrell MI, Iritani BM, Ruddell A (2007) Tumor-induced sentinel lymph node lymphangiogenesis and increased lymph flow precede melanoma metastasis. Am J Pathol 170:774-786

He Y, K-i Kozaki, Karpanen T, Koshikawa K, Yla-Herttuala S, Takahashi T, Alitalo K (2002) Suppression of tumor lymphangiogenesis and lymph node metastasis by blocking vascular endothelial growth factor receptor 3 signaling. J Natl Cancer Inst 94:819-825

He Y, Rajantie I, Ilmonen M, Makinen T, Karkkainen MJ, Haiko P, Salven P, Alitalo K (2004) Preexisting lymphatic endothelium but not endothelial progenitor cells are essential for tumor lymphangiogenesis and lymphatic metastasis. Cancer Res 64:3737-3740

He Y, Rajantie I, Pajusola K, Jeltsch M, Holopainen T, Yla-Herttuala S, Harding T, Jooss K, Takahashi T, Alitalo K (2005) Vascular endothelial cell growth factor receptor 3-mediated activation of lymphatic endothelium is crucial for tumor cell entry and spread via lymphatic vessels. Cancer Res 65:4739-4746

Hirakawa S, Kodama S, Kunstfeld R, Kajiya K, Brown LF, Detmar M (2005) VEGF-A induces tumor and sentinel lymph node lymphangiogenesis and promotes lymphatic metastasis. J Exp Med 201:1089-1099

Hirakawa S, Brown LF, Kodama S, Paavonen K, Alitalo K, Detmar M (2007) VEGF-C-induced lymphangiogenesis in sentinel lymph nodes promotes tumor metastasis to distant sites. Blood 109:1010-1017

Hirashima M, Sano K, Morisada T, Murakami K, Rossant J, Suda T (2008) Lymphatic vessel assembly is impaired in Aspp1-deficient mouse embryos. Dev Biol 316:149-159

Hoerauf A, Mand S, Fischer K, Kruppa T, Marfo-Debrekyei Y, Debrah AY, Pfarr KM, Adjei O, Büttner DW (2003) Doxycycline as a novel strategy against bancroftian filariasis-depletion of Wolbachia endosymbionts from Wuchereria bancrofti and stop of microfilaria production. Med Microbiol Immunol 192:211-216

Hong Y-K, Harvey N, Noh Y-H, Schacht V, Hirakawa S, Detmar M, Oliver G (2002) Prox1 is a master control gene in the program specifying lymphatic endothelial cell fate. Dev Dyn 225:351-357

Hoshida T, Isaka N, Hagendoorn J, di Tomaso E, Chen Y-L, Pytowski B, Fukumura D, Padera TP, Jain RK (2006) Imaging steps of lymphatic metastasis reveals that vascular endothelial growth factor$\mathrm{C}$ increases metastasis by increasing delivery of cancer cells to lymph nodes: therapeutic implications. Cancer Res 66:80658075

Huang XZ, Wu JF, Ferrando R, Lee JH, Wang YL, Farese RV Jr, Sheppard D (2000) Fatal bilateral chylothorax in mice lacking the integrin alpha 9beta 1. Mol Cell Biol 20:5208-5215

Huntington GC, Mc Clure CFW (1910) The anatomy and development of the jugular lymph sacs in the domestic cat (Felis domestica). Am J Anat 10:177-311

Ichikawa-Shindo Y, Sakurai T, Kamiyoshi A, Kawate H, Inuma N, Yoshizawa T, Koyama T, Fukuchi J, Iimuro S, Moriyama N,
Kawakami H, Murata T, Kangawa K, Nagai R, Shindo T (2008) The GPCR modulator protein RAMP2 is essential for angiogenesis and vascular integrity. J Clin Invest 118:29-39

Iljin K, Petrova TV, Veikkola T, Kumar V, Poutanen M, Alitalo K (2002) A fluorescent Tie1 reporter allows monitoring of vascular development and endothelial cell isolation from transgenic mouse embryos. FASEB J 16:1764-1774

Irjala H, Johansson E-L, Grenman R, Alanen K, Salmi M, Jalkanen S (2001) Mannose receptor is a novel ligand for L-Selectin and mediates lymphocyte binding to lymphatic endothelium. J Exp Med 194:1033-1042

Irrthum A, Karkkainen MJ, Devriendt K, Alitalo K, Vikkula M (2000) Congenital hereditary lymphedema caused by a mutation that inactivates VEGFR3 tyrosine kinase. Am J Hum Genet 67:295301

Irrthum A, Devriendt K, Chitayat D, Matthijs G, Glade C, Steijlen PM, Fryns J-P, Van Steensel MAM, Vikkula M (2003) Mutations in the transcription factor gene SOX18 underlie recessive and dominant forms of hypotrichosis-lymphedema-telangiectasia. Am J Hum Genet 72:1470-1478

Jackson DG (2004) Biology of the lymphatic marker LYVE-1 and applications in research into lymphatic trafficking and lymphangiogenesis. APMIS 112:526-538

Jeltsch M, Kaipainen A, Joukov V, Meng X, Lakso M, Rauvala H, Swartz M, Fukumura D, Jain RK, Alitalo K (1997) Hyperplasia of lymphatic vessels in VEGF-C transgenic mice. Science 276:1423-1425

Jin D, Harada K, Ohnishi S, Yamahara K, Kangawa K, Nagaya N (2008) Adrenomedullin induces lymphangiogenesis and ameliorates secondary lymphoedema. Cardiovasc Res. doi:10.1093/cvr/ cvn 228

Joukov V, Sorsa T, Kumar V, Jeltsch M, Claesson-Welsh L, Cao Y, Saksela O, Kalkkinen N, Alitalo K (1997) Proteolytic processing regulates receptor specificity and activity of VEGF-C. EMBO J 16:3898-3911

Joukov V, Kumar V, Sorsa T, Arighi E, Weich H, Saksela O, Alitalo K (1998) A recombinant mutant vascular endothelial growth factor-C that has lost vascular endothelial growth factor receptor-2 binding, activation, and vascular permeability activities. J Biol Chem 273:6599-6602

Kajiya K, Hirakawa S, Ma B, Drinnenberg I, Detmar M (2005) Hepatocyte growth factor promotes lymphatic vessel formation and function. EMBO J 24:2885-2895

Kajiya K, Hirakawa S, Detmar M (2006) Vascular endothelial growth factor-A mediates ultraviolet B-induced impairment of lymphatic vessel function. Am J Pathol 169:1496-1503

Karkkainen MJ, Ferrell RE, Lawrence EC, Kimak MA, Levinson KL, McTigue MA, Alitalo K, Finegold DN (2000) Missense mutations interfere with VEGFR-3 signalling in primary lymphoedema. Nat Genet 25:153-159

Karkkainen MJ, Saaristo A, Jussila L, Karila KA, Lawrence EC, Pajusola K, Bueler H, Eichmann A, Kauppinen R, Kettunen MI, YIÃHerttuala S, Finegold DN, Ferrell RE, Alitalo K (2001) A model for gene therapy of human hereditary lymphedema. Proc Natl Acad Sci USA 98:12677-12682

Karkkainen MJ, Haiko P, Sainio K, Partanen J, Taipale J, Petrova TV, Jeltsch M, Jackson DG, Talikka M, Rauvala H, Betsholtz C, Alitalo K (2004) Vascular endothelial growth factor $C$ is required for sprouting of the first lymphatic vessels from embryonic veins. Nat Immunol 5:74-80

Karpanen T, Alitalo K (2008) Molecular biology and pathology of lymphangiogenesis. Annu Rev Pathol Mech Dis 3:367-397

Karpanen T, Egeblad M, Karkkainen MJ, Kubo H, Yla-Herttuala S, Jaattela M, Alitalo K (2001) Vascular endothelial growth factor C promotes tumor lymphangiogenesis and intralymphatic tumor growth. Cancer Res 61:1786-1790 
Karpanen T, Heckman CA, Keskitalo S, Jeltsch M, Ollila H, Neufeld G, Tamagnone L, Alitalo K (2006a) Functional interaction of VEGF-C and VEGF-D with neuropilin receptors. FASEB J 20:1462-1472

Karpanen T, Wirzenius M, Makinen T, Veikkola T, Haisma HJ, Achen MG, Stacker SA, Pytowski B, Yla-Herttuala S, Alitalo K (2006b) Lymphangiogenic growth factor responsiveness is modulated by postnatal lymphatic vessel maturation. Am J Pathol 169:708-718

Kerjaschki D (2005) The crucial role of macrophages in lymphangiogenesis. J Clin Invest 115:2316-2319

Kerjaschki D, Regele HM, Moosberger I, Nagy-Bojarski K, Watschinger B, Soleiman A, Birner P, Krieger S, Hovorka A, Silberhumer G, Laakkonen P, Petrova T, Langer B, Raab I (2004) Lymphatic neoangiogenesis in human kidney transplants is associated with immunologically active lymphocytic infiltrates. J Am Soc Nephrol 15:603-612

Koyama H, Kobayashi N, Harada M, Takeoka M, Kawai Y, Sano K, Fujimori M, Amano J, Ohhashi T, Kannagi R, Kimata K, Si Taniguchi, Itano N (2008) Significance of tumor-associated stroma in promotion of intratumoral lymphangiogenesis: pivotal role of a hyaluronan-rich tumor microenvironment. Am J Pathol 172:179_ 193

Kriederman BM, Myloyde TL, Witte MH, Dagenais SL, Witte CL, Rennels M, Bernas MJ, Lynch MT, Erickson RP, Caulder MS, Miura N, Jackson D, Brooks BP, Glover TW (2003) FOXC2 haploinsufficient mice are a model for human autosomal dominant lymphedema-distichiasis syndrome. Hum Mol Genet 12:11791185

Kubo H, Cao R, Brakenhielm E, Mäkinen T, Cao Y, Alitalo K (2002) Blockade of vascular endothelial growth factor receptor-3 signaling inhibits fibroblast growth factor-2-induced lymphangiogenesis in mouse cornea. Proc Natl Acad Sci USA 99:8868-8873

Küchler AM, Gjini E, Peterson-Maduro J, Cancilla B, Wolburg H, Schulte-Merker S (2006) Development of the zebrafish lymphatic system requires VEGFC signaling. Curr Biol 16:1244-1248

Kunstfeld R, Hirakawa S, Hong Y-K, Schacht V, Lange-Asschenfeldt B, Velasco P, Lin C, Fiebiger E, Wei X, Wu Y, Hicklin D, Bohlen P, Detmar M (2004) Induction of cutaneous delayed-type hypersensitivity reactions in VEGF-A transgenic mice results in chronic skin inflammation associated with persistent lymphatic hyperplasia. Blood 104:1048-1057

Kyzas PA, Geleff S, Batistatou A, Agnantis NJ, Stefanou D (2005) Evidence for lymphangiogenesis and its prognostic implications in head and neck squamous cell carcinoma. J Pathol 206:170-177

Langton PF, Colombani J, Aerne BL, Tapon N (2007) Drosophila ASPP regulates C-terminal Src kinase activity. Dev Cell 13:773782

Leak LV (1976) The structure of lymphatic capillaries in lymph formation. Fed Proc 35:1863-1871

Leak LV, Burke JF (1966) Fine structure of the lymphatic capillary and the adjoining connective tissue area. Am J Anat 118:785-809

Leak LV, Burke JF (1968) Ultrastructural studies on the lymphatic anchoring filaments. J Cell Biol 36:129-149

Lewis F (1905) The development of the lymphatic system in Rabbits. Am J Anat 5:95-111

Lin J, Lalani AS, Harding TC, Gonzalez M, Wu W-W, Luan B, Tu GH, Koprivnikar K, VanRoey MJ, He Y, Alitalo K, Jooss K (2005) Inhibition of lymphogenous metastasis using adeno-associated virus-mediated gene transfer of a soluble VEGFR-3 decoy receptor. Cancer Res 65:6901-6909

Mackay CR, Kimpton WG, Brandon MR, Cahill RN (1988) Lymphocyte subsets show marked differences in their distribution between blood and the afferent and efferent lymph of peripheral lymph nodes. J Exp Med 167:1755-1765

Makinen T, Adams RH, Bailey J, Lu Q, Ziemiecki A, Alitalo K, Klein $\mathrm{R}$, Wilkinson GA (2005) PDZ interaction site in ephrinB2 is required for the remodeling of lymphatic vasculature. Genes Dev 19:397-410

Mäkinen T, Veikkola T, Mustjoki S, Karpanen T, Catimel B, Nice EC, Wise L, Mercer A, Kowalski H, Kerjaschki D, Stacker SA, Achen MG, Alitalo K (2001) Isolated lymphatic endothelial cells transduce growth, survival and migratory signals via the VEGF-C/D receptor VEGFR-3. EMBO J 20:4762-4773

Mandala S, Hajdu R, Bergstrom J, Quackenbush E, Xie J, Milligan J, Thornton R, Shei G-J, Card D, Keohane C, Rosenbach M, Hale J, Lynch CL, Rupprecht K, Parsons W, Rosen H (2002) Alteration of lymphocyte trafficking by sphingosine-1-phosphate receptor agonists. Science 296:346-349

Mandriota SJ, Jussila L, Jeltsch M, Compagni A, Baetens D, Prevo R, Banerji S, Huarte J, Montesano R, Jackson DG, Orci L, Alitalo K, Christofori G, Pepper MS (2001) Vascular endothelial growth factor-C-mediated lymphangiogenesis promotes tumour metastasis. EMBO J 20:672-682

Maruyama K, Li M, Cursiefen C, Jackson DG, Keino H, Tomita M, Van Rooijen N, Takenaka H, D'Amore PA, Stein-Streilein J, Losordo DW, Streilein JW (2005) Inflammation-induced lymphangiogenesis in the cornea arises from CD11b-positive macrophages. J Clin Invest 115:2363-2372

Matloubian M, Lo CG, Cinamon G, Lesneski MJ, Xu Y, Brinkmann V, Allende ML, Proia RL, Cyster JG (2004) Lymphocyte egress from thymus and peripheral lymphoid organs is dependent on S1P receptor 1. Nature 427:355-360

Mellor RH, Brice G, Stanton AWB, French J, Smith A, Jeffery S, Levick JR, Burnand KG, Mortimer PS (2007) Mutations in FOXC2 are strongly associated with primary valve failure in veins of the lower limb. Circulation 115:1912-1920

Melrose WD (2002) Lymphatic filariasis: new insights into an old disease. Int J Parasitol 32:947-960

Mishima K, Watabe T, Saito A, Yoshimatsu Y, Imaizumi N, Masui S, Hirashima M, Morisada T, Oike Y, Araie M, Niwa H, Kubo H, Suda T, Miyazono K (2007) Prox1 induces lymphatic endothelial differentiation via integrin $\{$ alpha 99 and other signaling cascades. Mol Biol Cell 18:1421-1429

Moore (1985) Clinically orientated anatomy. Williams \& Wilkins, Baltimore, pp 42-45

Morisada T, Oike Y, Yamada Y, Urano T, Akao M, Kubota Y, Maekawa H, Kimura Y, Ohmura M, Miyamoto T, Nozawa S, Koh GY, Alitalo K, Suda T (2005) Angiopoietin-1 promotes LYVE-1-positive lymphatic vessel formation. Blood 105:4649-4656

Navarro A, Perez RE, Rezaiekhaligh M, Mabry SM, Ekekezie II (2008) T1 \{alpha\}/podoplanin is essential for capillary morphogenesis in lymphatic endothelial cells. Am J Physiol Lung Cell Mol Physiol 295(4):L543-L551

Ny A, Koch M, Schneider M, Neven E, Tong RT, Maity S, Fischer C, Plaisance S, Lambrechts D, Héligon C, Terclavers S, Ciesiolka M, Kälin R, Man WY, Senn I, Wyns S, Lupu F, Brändli A, Vleminckx K, Collen D, Dewerchin M, Conway EM, Moons L, Jain RK, Carmeliet P (2005) A genetic Xenopus laevis tadpole model to study lymphangiogenesis. Nat Med 11:998-1004

Ohl L, Mohaupt M, Czeloth N, Hintzen G, Kiafard Z, Zwirner J, Blankenstein T, Henning G, Förster R (2004) CCR7 governs skin dendritic cell migration under inflammatory and steady-state conditions. Immunity 21:279-288

Oka M, Iwata C, Suzuki HI, Kiyono K, Morishita Y, Watabe T, Komuro A, Kano MR, Miyazono K (2008) Inhibition of endogenous TGF- $\{$ beta $\}$ signaling enhances lymphangiogenesis. Blood 111:4571-4579

Oliver G (2004) Lymphatic vasculature development. Nat Rev Immunol 4:35-45

Oliver G, Detmar M (2002) The rediscovery of the lymphatic system: old and new insights into the development and biological function of the lymphatic vasculature. Genes Dev 16:773-783 
Paavonen K, Puolakkainen P, Jussila L, Jahkola T, Alitalo K (2000) Vascular endothelial growth factor receptor-3 in lymphangiogenesis in wound healing. Am J Pathol 156:1499-1504

Paavonen K, Mandelin J, Partanen T, Jussila L, Li TF, Ristimaki A, Alitalo K, Konttinen YT (2002) Vascular endothelial growth factors $\mathrm{C}$ and D and their VEGFR-2 and 3 receptors in blood and lymphatic vessels in healthy and arthritic synovium. J Rheumatol 29:39-45

Padera TP, Kadambi A, di Tomaso E, Carreira CM, Brown EB, Boucher Y, Choi NC, Mathisen D, Wain J, Mark EJ, Munn LL, Jain RK (2002) Lymphatic metastasis in the absence of functional intratumor lymphatics. Science 296:1883-1886

Pepper M, Tille J-C, Nisato R, Skobe M (2003) Lymphangiogenesis and tumor metastasis. Cell Tissue Res 314:167-177

Petrova TV, Mäkinen T, Mäkelä TP, Saarela J, Virtanen I, Ferrell RE, Finegold DN, Kerjaschki D, Ylä-Herttuala S, Alitalo K (2002) Lymphatic endothelial reprogramming of vascular endothelial cells by the Prox-1 homeobox transcription factor. EMBO J 21:4593-4599

Petrova TV, Karpanen T, Norrmen C, Mellor R, Tamakoshi T, Finegold D, Ferrell R, Kerjaschki D, Mortimer P, Yla-Herttuala S, Miura N, Alitalo K (2004) Defective valves and abnormal mural cell recruitment underlie lymphatic vascular failure in lymphedema distichiasis. Nat Med 10:974-981

Purhonen S, Palm J, Rossi D, Kaskenpaa N, Rajantie I, Yla-Herttuala S, Alitalo K, Weissman IL, Salven P (2008) Bone marrow-derived circulating endothelial precursors do not contribute to vascular endothelium and are not needed for tumor growth. Proc Natl Acad Sci USA 105:6620-6625

Qi H, Egen JG, Huang AYC, Germain RN (2006) Extrafollicular activation of lymph node B cells by antigen-bearing dendritic cells. Science 312:1672-1676

Religa P, Cao R, Bjorndahl M, Zhou Z, Zhu Z, Cao Y (2005) Presence of bone marrow-derived circulating progenitor endothelial cells in the newly formed lymphatic vessels. Blood 106:4184-4190

Ristimaki A, Narko K, Enholm B, Joukov V, Alitalo K (1998) Proinflammatory cytokines regulate expression of the lymphatic endothelial mitogen vascular endothelial growth factor-C. J Biol Chem 273:8413-8418

Roberts N, Kloos B, Cassella M, Podgrabinska S, Persaud K, Wu Y, Pytowski B, Skobe M (2006) Inhibition of VEGFR-3 activation with the antagonistic antibody more potently suppresses lymph node and distant metastases than inactivation of VEGFR-2. Cancer Res 66:2650-2657

Rockson SG (2001) Lymphedema. Am J Med 110:288-295

Saban MR, Memet S, Jackson DG, Ash J, Roig AA, Israel A, Saban R (2004) Visualization of lymphatic vessels through NF-\{kappa\}B activity. Blood 104:3228-3230

Sabin FR (1902) On the origin of the lymphatic system from the veins and the development of the lymph hearts and thoracic ducts in the pig. Am J Anat 1:367-389

Sabin FR (1909) The lymphatic system in human embryos, with a consideration of the morphology of the system as a whole. Am J Anat 9:43-91

Sacchi G, Weber E, Agliano M, Raffaelli N, Comparini L (1997) The structure of superficial lymphatics in the human thigh: precollectors. Anat Rec 247:53-62

Saeki H, Moore AM, Brown MJ, Hwang ST (1999) Cutting edge: secondary lymphoid-tissue chemokine (SLC) and CC chemokine receptor 7 (CCR7) participate in the emigration pathway of mature dendritic cells from the skin to regional lymph nodes. J Immunol 162:2472-2475

Saharinen P, Petrova TV (2004) Molecular Regulation of Lymphangiogenesis. Ann NY Acad Sci 1014:76-87

Saharinen P, Kerkela K, Ekman N, Marron M, Brindle N, Lee GM, Augustin H, Koh GY, Alitalo K (2005) Multiple angiopoietin recombinant proteins activate the Tie 1 receptor tyrosine kinase and promote its interaction with Tie2. J Cell Biol 169:239-243

Saito Y, Nakagami H, Morishita R, Takami Y, Kikuchi Y, Hayashi H, Nishikawa T, Tamai K, Azuma N, Sasajima T, Kaneda Y (2006) Transfection of human hepatocyte growth factor gene ameliorates secondary lymphedema via promotion of lymphangiogenesis. Circulation 114:1177-1184

Sallusto F, Schaerli P, Loetscher P, Schaniel C, Lenig D, Mackay CR, Qin S, Lanzavecchia A (1998) Rapid and coordinated switch in chemokine receptor expression during dendritic cell maturation. Eur J Immunol 28:2760-2769

Salmi M, Koskinen K, Henttinen T, Elima K, Jalkanen S (2004) CLEVER-1 mediates lymphocyte transmigration through vascular and lymphatic endothelium. Blood 104:3849-3857

Scavelli C, Weber E, Aglianò M, Cirulli T, Nico B, Vacca A, Ribatti D (2004) Lymphatics at the crossroads of angiogenesis and lymphangiogenesis. J Anat 204:433-449

Schacht V, Ramirez MI, Hong YK, Hirakawa S, Feng D, Harvey N, Williams M, Dvorak AM, Dvorak HF, Oliver G, Detmar M (2003) T1alpha/podoplanin deficiency disrupts normal lymphatic vasculature formation and causes lymphedema. EMBO J 22:3546-3556

Schledzewski K, Falkowski M, Moldenhauer G, Metharom P, Kzhyshkowska J, Ganss R, Demory A, Falkowska-Hansen B, Kurzen H, Ugurel S, Geginat G, Arnold B, Goerdt S (2006) Lymphatic endothelium-specific hyaluronan receptor LYVE-1 is expressed by stabilin-1+, F4/80+, CD11b+ macrophages in malignant tumours and wound healing tissue in vivo and in bone marrow cultures in vitro: implications for the assessment of lymphangiogenesis. J Pathol 209:67-77

Schmid-Schönbein G (2003) The second valve system in lymphatics. Lymphat Res Biol 1:25-29

Schoppmann SF, Birner P, Stockl J, Kalt R, Ullrich R, Caucig C, Kriehuber E, Nagy K, Alitalo K, Kerjaschki D (2002) Tumorassociated macrophages express lymphatic endothelial growth factors and are related to peritumoral lymphangiogenesis. Am J Pathol 161:947-956

Sebzda E, Hibbard C, Sweeney S, Abtahian F, Bezman N, Clemens G, Maltzman JS, Cheng L, Liu F, Turner M, Tybulewicz V, Koretzky GA, Kahn ML (2006) Syk and Slp-76 Mutant Mice Reveal a Cell-Autonomous Hematopoietic Cell Contribution to Vascular Development. Dev Cell 11:349-361

Shibata MA, Morimoto J, Shibata E, Otsuki Y (2008) Combination therapy with short interfering RNA vectors against VEGF-C and VEGF-A suppresses lymph node and lung metastasis in a mouse immunocompetent mammary cancer model. Cancer Gene Ther. doi:10.1038/cgt.2008.43

Shields JD, Emmett MS, Dunn DBA, Joory KD, Sage LM, Rigby H, Mortimer PS, Orlando A, Levick JR, Bates DO (2006) Chemokine-mediated migration of melanoma cells towards lymphaticsa mechanism contributing to metastasis. Oncogene 26:2997-3005

Shin JW, Min M, Larrieu-Lahargue F, Canron X, Kunstfeld R, Nguyen L, Henderson JE, Bikfalvi A, Detmar M, Hong Y-K (2006) Prox 1 promotes lineage-specific expression of fibroblast growth factor (FGF) receptor-3 in lymphatic endothelium: a role for FGF signaling in lymphangiogenesis. Mol Biol Cell 17:576-584

Skobe M, Hawighorst T, Jackson DG, Prevo R, Janes L, Velasco P, Riccardi L, Alitalo K, Claffey K, Detmar M (2001) Induction of tumor lymphangiogenesis by VEGF-C promotes breast cancer metastasis. Nat Med 7:192-198

Solito R, Alessandrini C, Fruschelli M, Pucci AM, Gerli R (1997) An immunological correlation between the anchoring filaments of initial lymph vessels and the neighboring elastic fibers: a unified morphofunctional concept. Lymphology 30:194-202

Srinivasan RS, Dillard ME, Lagutin OV, Lin FJ, Tsai S, Tsai MJ, Samokhvalov IM, Oliver G (2007) Lineage tracing demonstrates the 
venous origin of the mammalian lymphatic vasculature. Genes Dev 21:2422-2432

Stacker SA, Caesar C, Baldwin ME, Thornton GE, Williams RA, Prevo R, Jackson DG, S-i Nishikawa, Kubo H, Achen MG (2001) VEGF-D promotes the metastatic spread of tumor cells via the lymphatics. Nat Med 7:186-191

Stacker SA, Achen MG, Jussila L, Baldwin ME, Alitalo K (2002a) Metastasis: lymphangiogenesis and cancer metastasis. Nat Rev Cancer 2:573-583

Stacker SA, Baldwin ME, Achen MG (2002b) The role of tumor lymphangiogenesis in metastatic spread. FASEB J 16:922-934

Stolk WA, de Vlas SJ, Habbema JDF (2005) Anti-Wolbachia treatment for lymphatic filariasis. Lancet 365:2067-2068

Takakura N, Watanabe T, Suenobu S, Yamada Y, Noda T, Ito Y, Satake M, Suda T (2000) A role for hematopoietic stem cells in promoting angiogenesis. Cell 102:199-209

Tammela T, Petrova TV, Alitalo K (2005a) Molecular lymphangiogenesis: new players. Trends Cell Biol 15:434-441

Tammela T, Saaristo A, Lohela M, Morisada T, Tornberg J, Norrmen C, Oike Y, Pajusola K, Thurston G, Suda T, Yla-Herttuala S, Alitalo K (2005b) Angiopoietin-1 promotes lymphatic sprouting and hyperplasia. Blood 105:4642-4648

Tammela T, Saaristo A, Holopainen T, Lyytikka J, Kotronen A, Pitkonen M, Abo-Ramadan U, Yla-Herttuala S, Petrova TV, Alitalo K (2007) Therapeutic differentiation and maturation of lymphatic vessels after lymph node dissection and transplantation. Nat Med 13:1458-1466

Tammela T, Zarkada G, Wallgard E, Murtomaki A, Suchting S, Wirzenius M, Waltari M, Hellstrom M, Schomber T, Peltonen R, Freitas C, Duarte A, Isoniemi H, Laakkonen P, Christofori G, Yla-Herttuala S, Shibuya M, Pytowski B, Eichmann A, Betsholtz C, Alitalo K (2008) Blocking VEGFR-3 suppresses angiogenic sprouting and vascular network formation. Nature 454:656-660

Taniguchi K, Kohno R-I, Ayada T, Kato R, Ichiyama K, Morisada T, Oike Y, Yonemitsu Y, Maehara Y, Yoshimura A (2007) Spreds are essential for embryonic lymphangiogenesis by regulating vascular endothelial growth factor receptor 3 signaling. Mol Cell Biol 27:4541-4550

Tobler NE, Detmar M (2006) Tumor and lymph node lymphangiogenesis-impact on cancer metastasis. J Leukoc Biol 80:691-696

Trzewik J, Mallipattu SK, Artmann GM, Delano FA, Schmid-Schonbein GW (2001) Evidence for a second valve system in lymphatics: endothelial microvalves. FASEB J 15:1711-1717

Valtola R, Salven P, Heikkila P, Taipale J, Joensuu H, Rehn M, Pihlajaniemi T, Weich H, deWaal R, Alitalo K (1999) VEGFR-3 and its ligand VEGF-C are associated with angiogenesis in breast cancer. Am J Pathol 154:1381-1390

Veikkola T, Jussila L, Makinen T, Karpanen T, Jeltsch M, Petrova TV, Kubo H, Thurston G, McDonald DM, Achen MG, Stacker SA, Alitalo K (2001) Signalling via vascular endothelial growth factor receptor-3 is sufficient for lymphangiogenesis in transgenic mice. EMBO J 20:1223-1231

Vlahakis NE, Young BA, Atakilit A, Sheppard D (2005) The Lymphangiogenic Vascular Endothelial Growth Factors VEGF-C and -D Are Ligands for the Integrin \{alpha\}9\{beta\}1. J Biol Chem 280:4544-4552

Vogel WOP, Claviez M (1981) Vascular specialization in fish, but no evidence for lymphatics. Z Naturforsch 36c:490-492

Wang JF, Zhang X-F, Groopman JE (2001) Stimulation of beta 1 integrin induces tyrosine phosphorylation of vascular endothelial growth factor receptor-3 and modulates cell migration. J Biol Chem 276:41950-41957

von der Weid PY, Zawieja DC (2004) Lymphatic smooth muscle: the motor unit of lymph drainage. Int J Biochem Cell Biol 36:1147-1153

Wicki A, Lehembre F, Wick N, Hantusch B, Kerjaschki D, Christofori $G$ (2006) Tumor invasion in the absence of epithelial-mesenchymal transition: Podoplanin-mediated remodeling of the actin cytoskeleton. Cancer Cell 9:261-272

Wigle JT, Oliver G (1999) Prox 1 function is required for the development of the murine lymphatic system. Cell 98:769-778

Wigle JT, Harvey N, Detmar M, Lagutina I, Grosveld G, Gunn MD, Jackson DG, Oliver G (2002) An essential role for Prox1 in the induction of the lymphatic endothelial cell phenotype. EMBO J 21:1505-1513

Wilting J, Aref Y, Huang R, Tomarev SI, Schweigerer L, Christ B, Valasek P, Papoutsi M (2006) Dual origin of avian lymphatics. Dev Biol 292:165-173

Wirzenius M, Tammela T, Uutela M, He Y, Odorisio T, Zambruno G, Nagy JA, Dvorak HF, Yla-Herttuala S, Shibuya M, Alitalo K (2007) Distinct vascular endothelial growth factor signals for lymphatic vessel enlargement and sprouting. J Exp Med 204:1431-1440

Wong SY, Haack H, Crowley D, Barry M, Bronson RT, Hynes RO (2005) Tumor-secreted vascular endothelial growth factor-C is necessary for prostate cancer lymphangiogenesis, but lymphangiogenesis is unnecessary for lymph node metastasis. Cancer Res 65:9789-9798

Wynd S, Melrose WD, Durrheim DN, Carron J, Gyapong M (2007) Understanding the community impact of lymphatic filariasis: a review of the sociocultural literature. Bull World Health Organ 85:493-498

Yaniv K, Isogai S, Castranova D, Dye L, Hitomi J, Weinstein BM (2006) Live imaging of lymphatic development in the zebrafish. Nat Med 12:711-716

Yildirim-Toruner C, Subramanian K, El Manjra L, Chen E, Goldstein S, Vitale E (2004) A novel frameshift mutation of FOXC2 gene in a family with hereditary lymphedema-distichiasis syndrome associated with renal disease and diabetes mellitus. Am J Med Genet A 131A:281-286

Yoon CM, Hong BS, Moon HG, Lim S, Suh P-G, Kim Y-K, Chae C-B, Gho YS (2008) Sphingosine-1-phosphate promotes lymphangiogenesis by stimulating S1P1/Gi/PLC/Ca2+ signaling pathways. Blood 112:1129-1138

Yuan L, Moyon D, Pardanaud L, Breant C, Karkkainen MJ, Alitalo K, Eichmann A (2002) Abnormal lymphatic vessel development in neuropilin 2 mutant mice. Development 129:4797-4806

Zlotnik A (2004) Chemokines in neoplastic progression. Semin Cancer Biol 14:181-185 